\title{
Svindel og bedrag
}

Tidsskriftet nr. 4/1917 åpnet med en lengre artikkel om de mørkere sidene ved moderne legemiddelindustri. Forfatteren bedyret først at «Der kan selvfølgelig ikke herske nogen tvil om, at forandringer er av det gode. Ingen kan ønske den gamle tilstand tilbake; thi den nye betyr et fremskridt, som ikke kan skattes høit nok». Men de store fremskrittene hadde en enorm skyggeside: uekte og falske produkter og legemidler ble solgt som noe annet enn de egentlig var, eller med løfter om umulige virkninger. I dag er det strenge regler for legemiddelreklame her i Norge, og for hundre år siden argumenterte denne skribenten for nettopp dette som løsning. Under følger deler av artikkelen (Tidsskr Nor Lægeforen 1917; 37: 113-23).

\section{Skyggesider ved moderne lagemiddelindustri.}

\section{Av E. Poulsson, professor i farmakologi, Kristiania}

(...) Verre er det, naar grove forfalskninger rammer vigtige lægemidler. I en stor sending medicin fra Italien til forbundsfællen Serbien, fandtes nylig, at kininpastillerne ikke indeholdt kinin, 90 pct. av antipyrinet var magnesiumsulfat, pyramidon og natriumsalicylat var erstattet med natriumbikarbonat og millioner av sublimatpastiller bestod av presset gips. For øieblikket er salvarsan og neosalvarsan utsat. 2 amerikanske prøver av neosalvarsan bestod av farvet koksalt, meget skjæbnesvangert for de patienter med primæraffektion, som ved tidlig behandling med det rigtige præparat kunde været reddet for den konstitutionelle syfilis.

For ikke længe siden var hos os forskjellige a rkan a en sand landeplage. Aviserne var fyldt av spaltelange avertissementer om de engelske Capsuloids, de franske Pinkpiller og et utal av amerikanske piller, som hjalp mot de forskjelligste sygdomme. Nogen av disse piller var strykninholdige og sandsynligvis skjødesløst tilberedt (en gut $\mathrm{i}$ Trondhjem døde av strykninforgiftning efter at ha tat 2 piller). Takket være vor gode, paa Medicinaldirektørens initiativ tilblevne arkanalov, er dette onde nu i alt væsentlig hævet.

Beslegtet med arkanatilvirkerne er imidlertid en talrik, fremdeles florerende klasse fabrikanter, som søker sit erhverv ved det, som tyskerne kalder «falsk deklarerte 1 æg e midler», midler som seiler under falsk flag, utgir sig for noget andet, end de er. En meget almindelig fremgangsmaate bestaar $\mathrm{i}$, at en blanding av forskjellige, ofte ganske almindelige og velkjendte midler utgives for at være en ny kemisk forbindelse, utrustes med en kemisk formel for at faa et videnskabelig skjær, forsynes med et fantasinavn og kastes ind paa markedet med stor reklame.

(...) Trods alt maa vi dog være tilfredse, saalænge reklamen holder sig i den medicinske presses spalter og saaledes kun kommer lægerne for øie. Langt skadeligere blir den, naar den i dagspressen henvender sig til det store publikum, som staar vergeløs og gjerne tror hvad der staar på trykk.

(...) Der kan ikke være tvil om, at e nhver paa det store publikum beregnet averterenav lægemidler eret o nde. Al saadan reklame vil med nødvendighet utarte; thi den honette mand vil altid ligge under; den, som skriker høiest og mindst generes av frygt for at støte an mot sandheten, den hvis devise det er at «verden vil bedrages», vil ha den største fremgang.

Hele dette uvæsen vilde forsvinde, og det vilde fra samfundets side kun være et berettiget selvforsvar, om al averteren av lægemidler i aviser, populære tidsskrifter o.o. ved lov blev helt forbudt. Et par svenske lægeforeninger har allerede for flere aar siden foreslaat dette og tilføiet, at forbudet ogsaa burde gjælde apparater bestemt til medi-

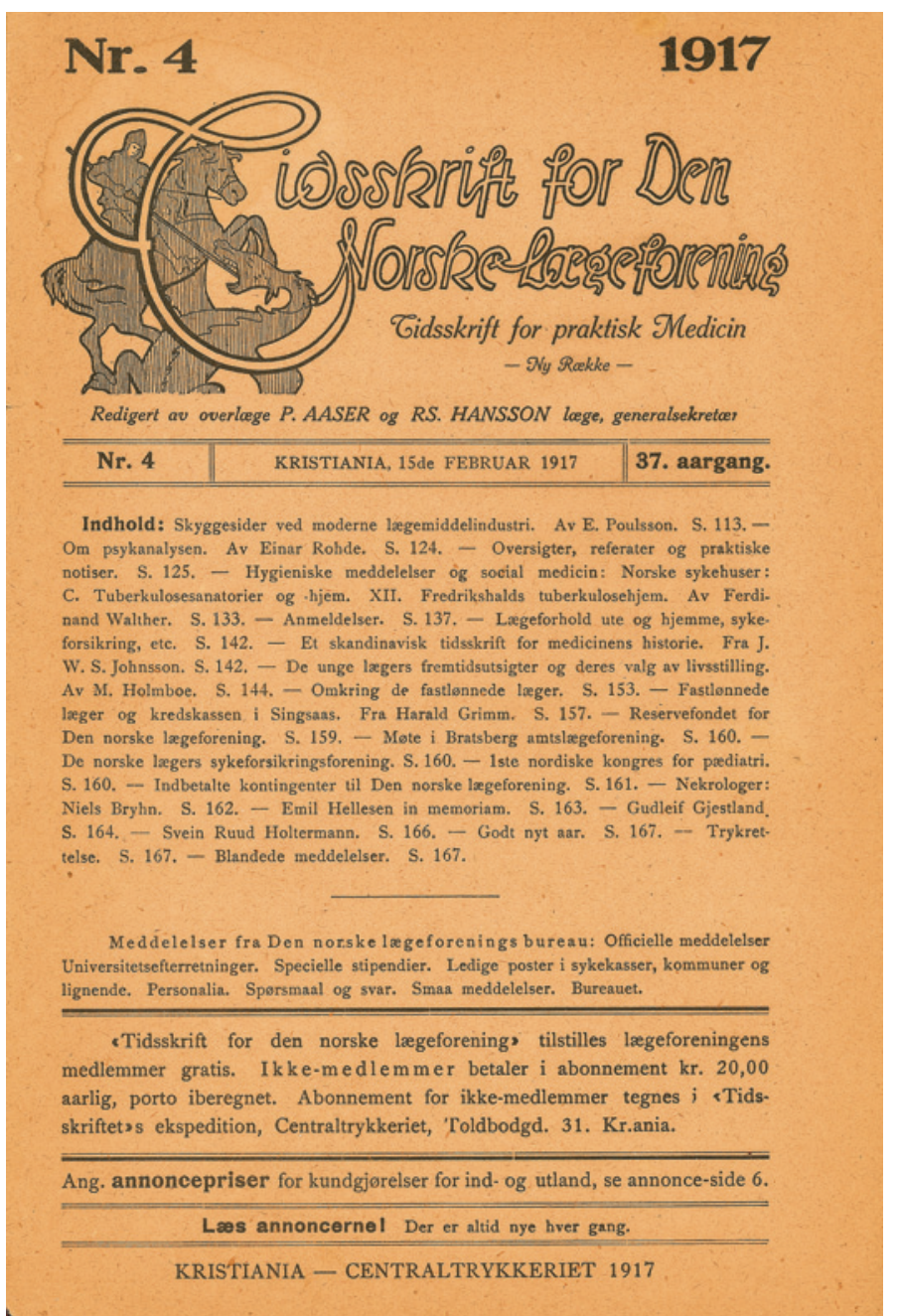

cinsk bruk (sandsynligvis sigtedes først og fremst til de «elektriske belter»). I motiverne anføres, at et saadant forbud eksisterer flere steder i utlandet.

Foreløbig kan vi læger paa egen haand utrette adskillig. Lægemiddelfabrikanternes avisreklame bør av os følges md større opmerksomhet og møtes paa en langt skarpere maate end hittil. (...) 